\title{
Impacts of soil and groundwater salinization on tree crop performance in post-tsunami Aceh Barat, Indonesia
}

\author{
C. Marohn ${ }^{1}$, A. Distel ${ }^{1}$, G. Dercon ${ }^{1, *}$, Wahyunto ${ }^{2}$, R. Tomlinson ${ }^{3}$, M. v. Noordwijk ${ }^{4}$, and G. Cadisch ${ }^{1}$ \\ ${ }^{1}$ Institute of Plant Production and Agroecology in the Tropics and Subtropics, University of Hohenheim, \\ 70593 Stuttgart, Germany \\ ${ }^{2}$ Indonesian Soil Research Institute, J1. Juanda 98, Bogor 16123, Indonesia \\ ${ }^{3}$ Catholic Relief Services, 228 W. Lexington St., Baltimore, Maryland, USA \\ ${ }^{4}$ World Agroforestry Centre, Jl. CIFOR, Sindang Barang, Bogor, Indonesia \\ * current address: Joint FAO/IAEA Division of Nuclear Techniques in Food and Agriculture, \\ International Atomic Energy Agency - IAEA, Wagramerstrasse 5, 1400, Vienna, Austria
}

Correspondence to: C. Marohn (marohn@uni-hohenheim.de)

Received: 21 March 2012 - Revised: 1 August 2012 - Accepted: 5 August 2012 - Published: 12 September 2012

\begin{abstract}
The Indian Ocean tsunami of December 2004 had far reaching consequences for agriculture in Aceh province, Indonesia, and particularly in Aceh Barat district, $150 \mathrm{~km}$ from the seaquake epicentre. In this study, the spatial distribution and temporal dynamics of soil and groundwater salinity and their impact on tree crops were monitored in Aceh Barat from 2006 to 2008. On 48 sampling points along ten transects, covering $40 \mathrm{~km}$ of coastline, soil and groundwater salinity were measured and related to mortality and yield depression of the locally most important tree crops. Given a yearly rainfall of over $3000 \mathrm{~mm}$, initial groundwater salinity declined rapidly from over 10 to less than $2 \mathrm{mS} \mathrm{cm}^{-1}$ within two years. On the other hand, seasonal dynamics of the groundwater table in combination with intrusion of saline water into the groundwater body led to recurring elevated salinity, sufficient to affect crops. Tree mortality and yield depression in the flooded area varied considerably between tree species. Damage to coconut (65\% trees damaged) was related to tsunami run-up height, while rubber $(50 \%$ trees damaged) was mainly affected by groundwater salinity. Coconut yields ( $-35 \%$ in average) were constrained by groundwater $\mathrm{Ca}^{2+}$ and $\mathrm{Mg}^{2+}$, while rubber yields $(-65 \%$ on average) were related to groundwater chloride, $\mathrm{pH}$ and soil sodium. These findings have implications on planting deeprooted tree crops as growth will be constrained by ongoing oscillations of the groundwater table and salinity.
\end{abstract}

\section{Introduction and scope}

On 26 December 2004, a seaquake with magnitude of 9.3 on the Richter scale close to the North Sumatran coast caused one of the most devastating tsunamis in recorded history. Worldwide, documented losses of human lives due to the disaster exceeded 250000 and more than 1 million people were displaced (Szczuciński et al., 2006). The province of Nanggroe Aceh Darussalam, and especially its district Aceh Barat, only $150 \mathrm{~km}$ from the epicentre, was most severely affected by the consequences of the seismic shock and the subsequent tsunami. Entire villages around the district capital Meulaboh were destroyed, and Shofiyati et al. (2005) reported that, out of 120295 ha flooded land in Aceh province, almost 19000 ha were situated in the district of Aceh Barat. Analysis of satellite imagery showed that more than $17 \%$ of over 200000 ha agricultural land surveyed in Aceh and almost $25 \%$ in Aceh Barat were affected by flooding due to the tsunami. While research on the role of vegetation to protect peoples' lives and property has been conducted in the area (Laso Bayas et al., 2011), information on tsunami impacts on agriculture is scarce.

Agriculture had been one of the most important sectors contributing to provincial employment and GDP before the tsunami (48\% and $32 \%$, respectively; CGI, 2005). The major crops grown by small-holders along the Acehnese west coast were paddy rice, vegetables, rubber, coconut, cocoa, fruit trees and, to a minor extent, oil palm (CGI, 2005). Tree 

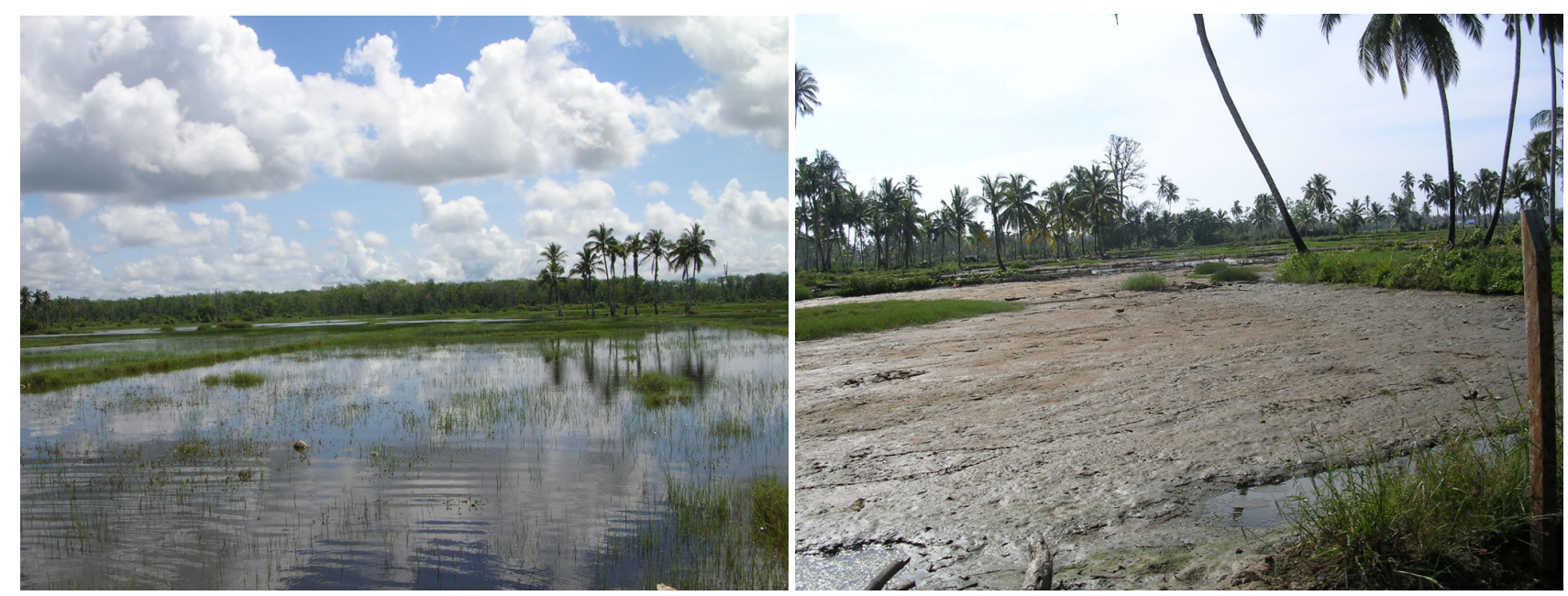

Fig. 1. (left) Subsided land $200 \mathrm{~m}$ from the sea in Suak Nie, near Meulaboh, Aceh Barat, Indonesia, as consequence of the earthquake, and (right) tsunami mud deposits, $100 \mathrm{~m}$ from the seashore.

crops, including natural vegetation such as Nypa fruticans, contributed 15 to $45 \%$ to the local pre-tsunami economy in the four coastal subdistricts of Aceh Barat (Joshi et al., 2007).

First projections after the disaster, usually based on remote sensing data and on electric conductivity (EC) measurements in shallow wells for drinking water, predicted dismal perspectives for agriculture in the province. Mid- to long-term reduction in crop productivity was expected even in moderately affected districts (CGI, 2005), and large areas were deemed to be permanently lost for agricultural use (Verrelst and Schaepman, 2007). Two main mechanisms were supposed to affect plants: (a) fast salinization caused by seawater inundation at the time of the tsunami and (b) exposure of roots to salts contained in tsunami deposits, by ingrowth or leaching, over a longer period. Additionally, for parts of the area, changed groundwater regime due to subsidence of land was expected to cause problems.

Mud-related problems in Aceh Barat arose mainly in paddies, where rice roots did not reach the water-logged horizons covered under thick sediments. In other parts of Aceh, high concentrations of $\mathrm{Mg}^{2+}$ were found in fresh tsunami sediments (Chaerun et al., 2008). Agus et al. (2008) and Rachman (2008) identified unbalanced ratios of $\mathrm{Na}^{+}, \mathrm{Ca}^{2+}$ and $\mathrm{Mg}^{2+}$ ions as a cause for empty pods in peanut and limited grain filling in rice. However, in some cases, plants actually benefited from tsunami mud. For example, farmers coined the term tsunami fertilizer, due to higher yields of vegetables obtained at mud-covered sites. For Sri Lanka, Chaudary et al. (2006) described improvements of soil texture, C, N and $\mathrm{P}$ due to tsunami mud.

For Aceh Barat, few data on soil and groundwater contamination existed as most post-tsunami research focused on Banda Aceh and Aceh Besar districts, more than $270 \mathrm{~km}$ northwest along the coast from the study area described in this paper. Despite the economic importance of tree crops, tsunami-related research was almost exclusively conducted on annual crops like paddy rice and vegetables (Agus et al., 2008). In contrast, trees are characterized by deep rooting systems, which make them more susceptible to soil and groundwater salinity, even though many trees dispose of detoxification by mechanisms like leaf shedding. It was assumed that tree growth was equally influenced by both groundwater and mud salinity (FAO, 2005; McLeod et al., 2010), whereas annuals were more affected by mud. Initially, farmers' reports on tree mortality and crop failure seemed to confirm these concerns. Although tree crop damage was widely evident in the landscape, underlying causes were not clear. For reconstruction of the agricultural sector in Aceh Barat it is, however, indispensable to understand the mechanisms causing tree crop damage and yield depression and to be able to predict their permanence in the mid- to long-term perspective.

Visual distinction of salinity-based factors leading to tree crop damage was mostly not possible. It was expected soon after the disaster that cation imbalances and, to minor extent, water stress would be the most serious mid-term constraints to plant production (Subiksa and Agus, 2008), followed by effects owed to a permanently changed groundwater table. Especially the long-term impact of ions, such as chloride $\left(\mathrm{Cl}^{-}\right)$, sodium $\left(\mathrm{Na}^{+}\right)$, and sulphate $\left(\mathrm{SO}^{2-}\right)$, gradually released from the tsunami mud, was expected to affect plant growth.

Post-tsunami studies carried out in Sri Lanka, India and Aceh Besar led to the hypothesis of the following major reasons for (tree) crop damage: (i) extreme mechanical forces of the tsunami resulting into breakage and uprooting of trees, mainly within the first kilometer from the coastline; (ii) subsidence caused by the earthquake, which irreversibly led to loss of land area to the sea, connection of freshwater bodies to the sea and permanent flooding in depressions further 


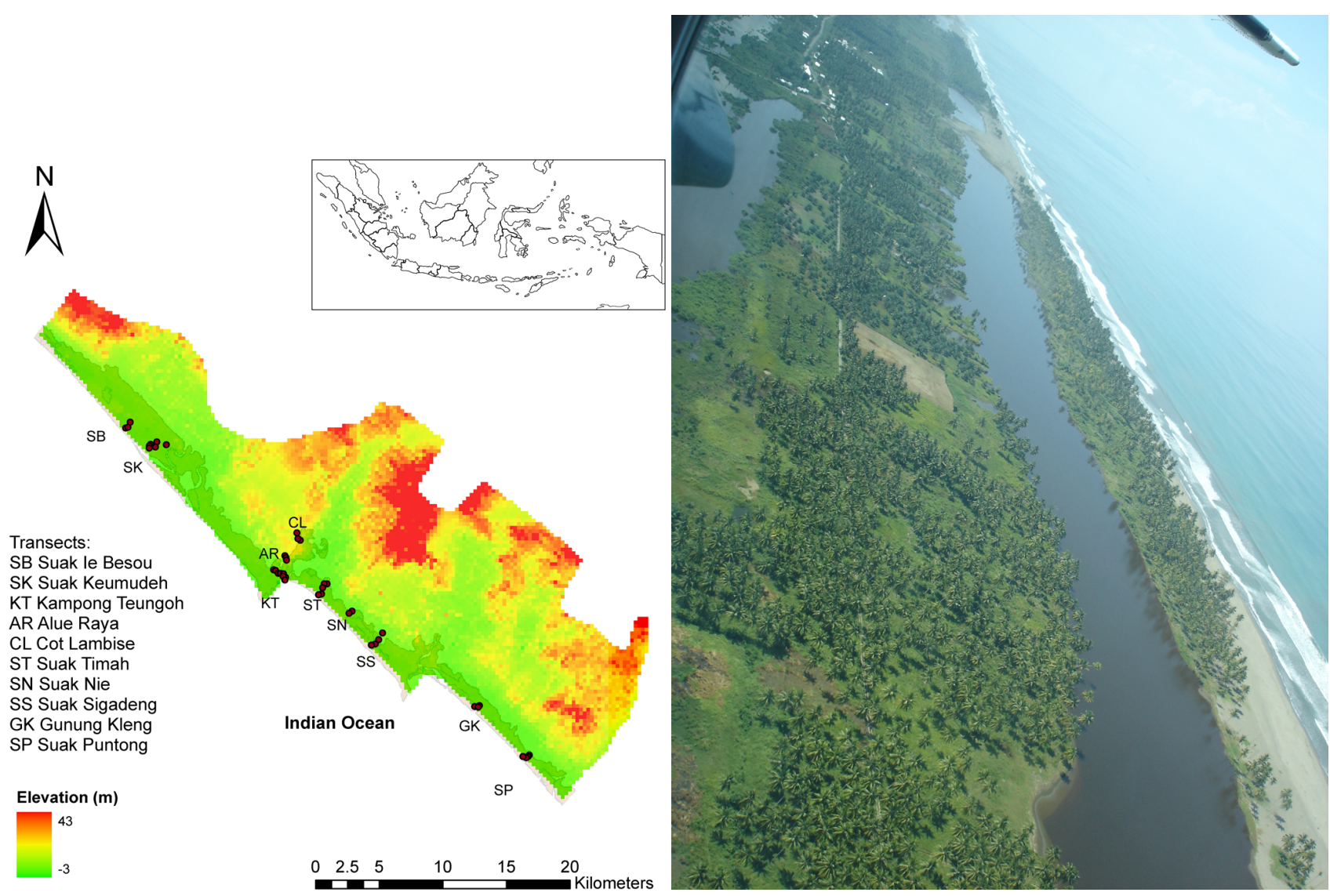

Fig. 2. (left) Digital elevation model extracted from Siemon et al. (2007) for the study area around Meulaboh during the tsunami event in Aceh, the westernmost province on the Indonesia map. Dots indicate the points sampled during this study; (right) ridges and swales parallel to the coast line about $15 \mathrm{~km} \mathrm{SE}$ of Meulaboh.

inland (Fig. 1a); (iii) inundation of the flat coastal landscape up to $5 \mathrm{~km}$ inland (Fig. 1b) and, depending upon residence time (Szczuciński et al., 2006), subsequent infiltration of saline water into the soil and groundwater (Villholth et al., 2005); and (iv) a deposition of saline tsunami mud of up to $1 \mathrm{~m}$ thickness, which buried plants or transformed paddy fields into free-draining soils (Fig. 1b).

This study aims at integrating spatial-temporal dynamics of salinization to tree crop damage as well as to specific growth-limiting factors, in order to understand mechanisms relevant to replanting of tree crop-based systems in coastal areas affected by tsunamis in the future. The specific objectives of the study were (i) to characterize spatial variability of salinization in groundwater and soils following the tsunami event of 2004; (ii) to assess seasonal variability of salinityrelated groundwater parameters; (iii) to relate mud cover as well as chemical properties of groundwater and soils to damage and yield depression of tree crops observed in the field; and (iv) to distinguish effects of the different limiting factors and deducting recommendations for tree crop rehabilitation in the aftermath of a tsunami event in tropical regions.

\section{Materials and methods}

\subsection{Study site description}

Research was carried out in the framework of the Re$\mathrm{GrIn}^{1}$ project along a coastal strip of $40 \mathrm{~km}$ around the town of Meulaboh, district capital of Aceh Barat, in Northern Sumatra (between $04^{\circ} 19^{\prime} 19.4^{\prime \prime} \mathrm{N}, 95^{\circ} 56^{\prime} 14.9^{\prime \prime} \mathrm{E}$ and $\left.04 .^{\circ} 05^{\prime} 14.1^{\prime \prime} \mathrm{N}, 96^{\circ} 12^{\prime} 57.1^{\prime \prime} \mathrm{E}\right)$. The coastline is relatively straight northwest - southeast oriented with two prominent tips shaped through estuaries (Fig. 2a). The area is subdivided by southwest oriented rivers that discharge into the Indian Ocean. Tsunami flooding extended up to $5 \mathrm{~km}$ land inward. Within the flooded area, apart from small dunes on the beach, topography is predominantly flat with a maximum elevation of approximately $5 \mathrm{~m}$ a.s.l., but characterized by sequences of narrow, shore-parallel ridges and swales (Fig. 2b).

Most coastal soils in Aceh Barat developed on recent marine and fluviatile alluvium (Siemon et al., 2007) and are classified as dystric Arenosols and dystric or thionic Gleysols

1 Rebuilding Green Infrastructure with Trees People Want, funded by the EU Eco ASIA IIb programme. 
according to the World Reference Base of Soil Resources (FAO, ISRIC and ISSS, 2006). In general, both soil types are characterized by low macronutrient contents, moderately acidic to slightly alkaline $\mathrm{pH}$ and sandy texture; the main criterion for distinction is groundwater depth. The bottom of the river valleys in the study area is characterized by more fertile Fluvisols (Wahyunto et al., 2009). Land inward acidic and organic soils, i.e. dystric Histosols (peat domes), can be found.

Before the 2004 tsunami event, land use on the marine soils was dominated by vegetables and fruit trees in the welldrained areas and paddy, fish ponds, Nypa fruticans, natural swamp vegetation in the water-logged parts, whereas coconut was grown across all (except water-logged) agroecological zones. Peat lands were predominantly under extensive "jungle rubber" but have been increasingly converted into oil palm plantations, vegetable and rice plots since 2005 . Alluvial soils along the rivers were used for paddy rice cultivation.

The coastal part of the district is characterized by a humid tropical climate with bimodal rainfall pattern. During the period relevant for this study (2004 to 2007), average annual rainfall amounted to more than $3600 \mathrm{~mm}$ with a drier interval between May and mid-September (Badan Meteorologi dan Geofisika, Meulaboh, 2008), which is characterized by relatively lower precipitation of less than $300 \mathrm{~mm} \mathrm{month}^{-1}$ and clearly deeper groundwater table. In May 2007, a flooding event not related to seasonal weather phenomena hit Aceh Barat. The flood was referred to as the most severe since the tsunami and inundated parts of the study area up to $500 \mathrm{~m}$ inland. Seawater resided for several days, affecting soils and destroying agricultural crops once again.

\subsection{Soil and groundwater sampling strategy}

Water quality in shallow drinking water wells in Aceh Barat had been monitored a few months after the tsunami (from May 2005 to September 2006) by the non-governmental organization Catholic Relief Services (CRS). This comprehensive dataset provided a baseline for the present study and gave valuable hints on spatial distribution of salinity as it showed that values decreased land inward, departing from the coast line and open water bodies connected to the sea. Accordingly, ten transects perpendicular to the coastline or radially departing from a large lagoon formed by the tsunami (from Kampong Teungoh to Alue Raya; see Fig. 2a) were laid out to monitor changes in soil and groundwater quality over distance from the coast and over time. In total, 48 permanent sampling points up to $1.5 \mathrm{~km}$ inland were selected to cover a representative share of the flooded area in the district of Aceh Barat. Sampling point denominations (as shown in Fig. 2a) were composed of the initials of the respective village name plus distance to the sea or lagoon in meters. Permanent PVC pipes were installed at each transect point to measure groundwater depth and extract water samples. Holes to a soil depth of up to $100 \mathrm{~cm}$ (less deep on a few plots where sandy soil collapsed below $\sim 50 \mathrm{~cm}$ ) were drilled using an auger. The pipes had been perforated below $50 \mathrm{~cm}$, so that only groundwater entered the pipes; the bottom of each pipe was closed with a plastic cap. Once a pipe had been inserted without soil compaction, washed gravel was filled in the space between soil matrix and pipe to establish soil contact and avoid vertical bypass flow outside the pipe. Samples were taken using a manual suction pump. The first pumping was always discarded and the sample taken once the groundwater level had reached the previous level. Thus, only groundwater was sampled that had entered the pipe at the time of sampling. $100 \mathrm{ml} \mathrm{PE}$ bottles were overfilled, cooled in styrofoam boxes and brought to the laboratory on the day of sampling, where they were analysed within $24 \mathrm{~h}$ after sampling.

At each transect point, composite soil samples made up of ten individual samples were collected in May 2007 over two depths: 0 to 20 and 20 to $40 \mathrm{~cm}$. Some of the sample plots were affected by a flood in May 2007 (in the results section, these values are marked with asterisks). All transect samples were analysed for $\mathrm{pH}, \mathrm{eC}$ and $\mathrm{Na}^{+}$and for $\mathrm{K}^{+}, \mathrm{Ca}^{2+}$ and $\mathrm{Mg}^{2+}$ in those cases where $\mathrm{Na}^{+}$was above $1 \mathrm{cmol} \mathrm{kg}^{-1}$. Two representative soil profiles (both near the Gunung Kleng transect, both not flooded in 2007) were analyzed by genetic horizon for the same parameters as the transect samples plus $\mathrm{N}, \mathrm{P}, \mathrm{K}$ and CEC to understand underlying pedogenic processes. Soil, land use and mud cover maps produced within the project were used as background information on patterns of salinity-related parameter values.

In order to account for seasonal differences in groundwater depth, field sampling campaigns during both drier and wetter seasons were conducted for two years, including dry season 2006, dry and wet season 2007 and wet season 2008. The flood event in May 2007 served as a proxy model for groundwater dynamics in 2005, immediately after the tsunami, which had not been surveyed. Continuous measurements of groundwater resistivity at $5 \mathrm{~m}$ depth, monitored in October 2005 during a helicopter survey along a grid of $500 \mathrm{~m}$ flight lines, sampling every 4 to $40 \mathrm{~m}$ by the German Federal Institute for Geosciences and Natural Resources BGR (Siemon et al., 2007), were extracted for each of the 48 transect points as additional information.

\subsection{Soil and groundwater analysis}

All soil samples collected from the reference profiles and transects were analyzed for texture (pipette method), $\mathrm{pH}$ in $0.01 \mathrm{M}$ calcium chloride $\left(\mathrm{CaCl}_{2}\right)$, electric conductivity (Thermo Orion 115A) and concentrations of basic cations (ammonium acetate method by Schollenberger and Simon, 1945, detection by atomic absorption, Varian Spectra AA55). For samples containing more than $1 \mathrm{cmol} \mathrm{Na}^{+} \mathrm{kg}^{-1}$ soil, the sodium adsorption ratio (SAR; dimensionless, with cations in $\mathrm{cmol} \mathrm{kg}^{-1}$, see Eq. 1) was computed: 
$\mathrm{SAR}=\frac{\mathrm{Na}^{+}}{\sqrt{\frac{\mathrm{Ca}^{2+}+\mathrm{Mg}^{2+}}{2}}}$.

SAR of soil extracts is defined as proportion of $\mathrm{Na}^{+}$in the adsorbed layer of clay minerals; it takes into account that the noxious effect of $\mathrm{Na}^{+}$is attenuated by the presence of calcium $\left(\mathrm{Ca}^{2+}\right)$ and magnesium $\left(\mathrm{Mg}^{2+}\right)$ ions. Above a SAR of 13, soil dispersion and high $\mathrm{pH}$ are expected to hamper water uptake into plants (Munshower, 1994).

Cation exchange capacity (CEC) was analyzed according to Schlichting et al. (1995), using a Hitachi U-2010 spectrophotometer for detection. Exchangeable acidity, the sum of aluminum $\left(\mathrm{Al}^{3+}\right)$ and hydrogen $\left(\mathrm{H}^{+}\right)$ions, was analyzed by the potassium chloride $(\mathrm{KCl})$ method following the procedure described by Pagel et al. (1982). Soil organic carbon (SOC) was analyzed by wet oxidation (Walkley and Black method). Total nitrogen (N) was determined using the Kjeldahl method (Schlichting et al., 1995) and available phosphorus (P) by Bray I (Bray and Kurtz, 1945). Soil electric resistivity $[\Omega \mathrm{m}]$, the reciprocal of electric conductivity measured at $5 \mathrm{~m}$ depth, was extracted from spatial helicopter survey data by BGR (Siemon et al., 2007).

Electric conductivity (EC) and $\mathrm{pH}$ of the groundwater samples were measured directly in the field using a portable HANNA Instruments (Woonsocket, RI, USA) device. Sulphate $\left(\mathrm{SO}_{4}^{2-}\right)$, chloride $\left(\mathrm{Cl}^{-}\right), \mathrm{Ca}^{2+}$ and $\mathrm{Mg}^{2+}$ in groundwater samples were determined at the CRS laboratory in Meulaboh within $24 \mathrm{~h}$ after sampling, following CRS standard procedures applied for the baseline survey in 2006: $\mathrm{SO}_{4}^{2-}$ was tested using a sulphate turb tablet. For $\mathrm{Cl}^{-}$, one acidifying $\mathrm{CD}$ tablet and, later, one chloridol tablet were used. For $\mathrm{Ca}^{2+}$ and $\mathrm{Mg}^{2+}$ extraction, calcicol no. 1 and magnicol tablets (all tablets: Palintest Ltd, UK), respectively, were used. Reagents needed for $\mathrm{Na}^{+}$were not available during the time of this study. Detection was photometric for all ions using a 5000 Equip (Wagtech, UK) device.

\subsection{Assessment of tree crop damage and yield depression}

For each sampling point and its surroundings, land use surveys were carried out from May to June (drier season) 2007. Twenty-four interviews with one or more farmers, preferentially owners of surveyed plots and village headmen, who had a wider overview over communal activities, were conducted. Structured questions on mortality and yield loss of tree crops on the transect plots and observations in the village such as area flooded, thickness of mud cover, subsidence, plus open questions on land use change after the tsunami including community action initialised by NGO (nurseries and replanting of "improved rubber" systems, fish ponds, new varieties, species, pasture for animals) were asked. Farmers were also asked to hypothesize possible mechanisms of tree damage caused by tsunami effects. This mixture allowed triangulation of responses to questions asked from different angles. Also, asking farmers about wider areas, not only their own land, allowed to cross-check information referring to spatially overlapping areas. Observations by farmers on plant damage and yield depression were documented for coconut (Cocos nucifera), rubber (Hevea brasiliensis), rambutan (Nephelium lappaceum), cocoa (Theobroma cacao), oil palm (Elaeis guineensis) and mango (Mangifera indica). Damage was quantified as mortality rates (\% of individuals). Yield depression refers to the reduction in yields as compared to average quantities per tree before the tsunami as observed by the farmers. Yield depression of $100 \%$ indicates total loss. Farmers' replies were cross-checked with observations taken during this study on run-up height from water marks, existing subsidence, and mud cover along the transect; tree mortality was estimated following the same criteria used in the farmer interviews: Quantification of tree damage was obtained as percentage counts of damaged trees on the plot, average visual percentage estimates of leaf chlorosis/necrosis and signs of parasites or diseases per tree as well as explanatory observations like water-logging. Interviews and observations included the listed species, but also other agricultural plants like guava, durian, sugar palm and several annual crops.

\subsection{Statistical analysis}

Soil and groundwater parameters at different times were correlated to tree damage and yield loss up to the end of May 2007 (survey date). Most parameters were not normally distributed, so that Spearman correlations (abbreviated $r_{\mathrm{S}}$ ) were calculated to draw conclusions on causal relationships among measured parameters, and Wilcoxon tests were employed to determine significant differences between observation times. As yields were expected to follow optimum curves of cation concentrations, second-order polynomial regressions were used to approximate yield reduction. Where all observations of a parameter remained below optimum conditions, linear relationships were preferred to avoid overfitting. All calculations were computed using SPSS 16.0 software. Polynomial, second-order regressions were calculated in Sigma Plot 10.0. The term significant (symbolized by *) is used to describe correlations with $\alpha<0.05$ and highly significant (or **) for $\alpha<0.01$.

\section{Results}

\subsection{Spatial distribution of salinity-related parameters in soil and groundwater}

Two soil profiles on the Gunung Kleng transect represented typical pedogenic and tsunami-related processes. The first profile, a novic Arenosol, was located at $04^{\circ} 07^{\prime} 10.5^{\prime \prime} \mathrm{N}$, $96^{\circ} 10^{\prime} 42.3^{\prime \prime} \mathrm{E}, 300 \mathrm{~m}$ from the shoreline on a ridge and thus 
not under permanent groundwater influence (groundwater table at excavation was at $-0.55 \mathrm{~m}$ depth). The plot was under grassland and had been a home garden until 2004.

A clearly distinct greyish and relatively sandy novic horizon of tsunami mud between 5 and $10 \mathrm{~cm}$ depth (Anv2) was overlain by another novic horizon (Anv1), which may have resembled the original A horizon and was probably deposited on site by the tsunami backwash (Table 1). Most analyzed parameters in the Anv2 showed sharp leaps as compared to the underlying horizons, e.g. lower soil organic carbon (SOC), total N, CEC, $\mathrm{Na}^{+}$and $\mathrm{Ca}^{2+}$ contents. Available $\mathrm{P}$ was found in very low concentrations (close to the detection limit of the method) in both profiles, so that leaps are not interpreted here. $\mathrm{Na}^{+}$was not present in high concentrations; its leaching front was found at the temporarily groundwaterinfluenced Bw2 horizon.

The second representative soil unit was an arenic Gleysol located at $04^{\circ} 07^{\prime} 18.9^{\prime \prime} \mathrm{N}, 96^{\circ} 10^{\prime} 52.6^{\prime \prime} \mathrm{E}$ in a depression and under grassland, which had been a rice paddy before the tsunami. The profile was further developed than the above-described Arenosol. Higher contents of organic matter, higher CEC, $\mathrm{pH}$ and basic cation concentrations as compared to the Arenosol, and higher $\mathrm{pH}, \mathrm{C}, \mathrm{N}$ and clay contents above $28 \mathrm{~cm}$ as compared to the subsoil appear to be outcomes of puddling, burning and fertilizer application during paddy use (Table 2). The soil had been ploughed after the tsunami, so that differences between horizons could not be attributed to mud deposition.

In both cases, the sandy texture facilitated leaching and thus desalinization. Peaks of EC and $\mathrm{Na}^{+}$in the B horizons ( $\mathrm{Bg}$ and $\mathrm{Bg}-\mathrm{Bw}$ ) of the Arenosol profile and the generally higher $\mathrm{Na}^{+}, \mathrm{Ca}^{2+}$ and $\mathrm{Mg}^{2+}$ concentrations and $\mathrm{EC}$ in the Gleysol suggest that groundwater oscillations after the tsunami still influenced soil salinity.

The survey of groundwater quality in shallow drinking water wells and boreholes conducted by the Catholic Relief Services in 2005 to 2006 showed that the Indonesian threshold for drinking water of $1 \mathrm{mS} \mathrm{cm}^{-1}$ had been surpassed at $18 \%$ of the sampled locations, mainly around river valleys and water bodies connected to the open sea. This general tendency of highest values close to seawater bodies was still apparent in 2007 on the ten transects surveyed for this study (Fig. 3). Groundwater EC by far exceeded soil EC across the majority of plots. Groundwater $\mathrm{Cl}$ (average 123, maximum $500 \mathrm{ppm}$ ) and $\mathrm{SO}_{4}^{2-}$ (average 48, maximum $201 \mathrm{ppm}$ ) concentrations measured on these transects (data not shown) were in general not constraining for agriculture. Groundwater EC was generally more variable than soil EC and, although there was no significant correlation, both parameters followed a similar trend.

Where small-scale relief features and smaller water bodies oriented parallel to the seashore (see Fig. 2b) were not present (transects AR, SS and most of CL), soil EC decreased with distance from salt water bodies (Fig. 3). Apart from the distance to the lagoon, the sequences KT, AR,

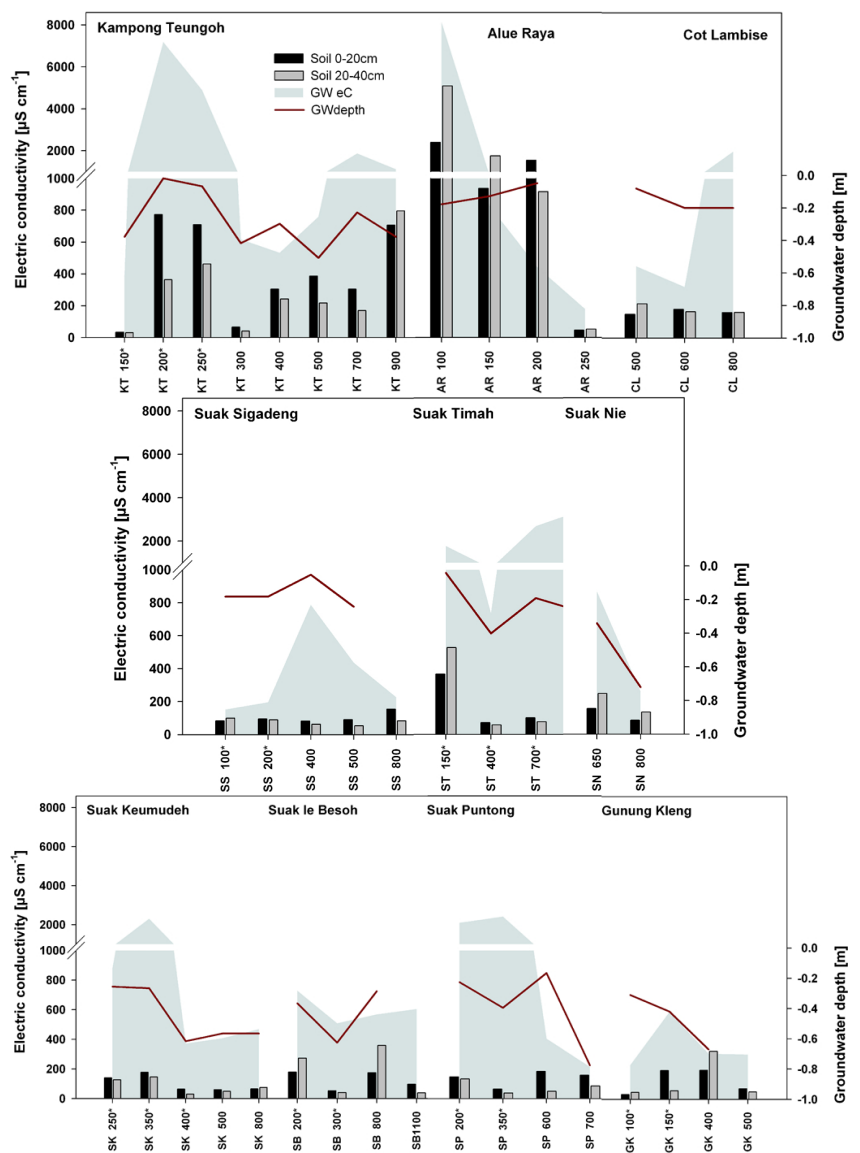

Fig. 3. Spatial distribution of soil and groundwater electric conductivity and groundwater depth in 2007. Plot indices are composed of village code and distance to seawater $(\mathrm{m})$. Asterisks indicate plots flooded in May 2007.

$\mathrm{CL}$ also describe an elevational gradient, so that the relatively lower soil salinity on transect CL (Cot Lambise the Acehnese name describes an elevated place) was owed to its altitude. More clearly and generally than elevation, groundwater depth could be related to salinity. Coast parallel swales and channels partly overruled distance to the sea in their impact on salinity levels (e.g. on transects KT, ST, SK and SB). On transect ST, a system of drainage channels influenced groundwater dynamics. All soils were categorized as non-saline ( $\mathrm{EC}<2 \mathrm{mS} \mathrm{cm}^{-1}$ for sensitive plants; FAO, 2005) except for AR100, located close to the lagoon created by the tsunami. On plots with soil $\mathrm{Na}^{+}$concentrations $>1 \mathrm{cmol} \mathrm{kg}^{-1}$, detrimental effects on tree crops were expected and $\mathrm{Ca}^{2+}, \mathrm{Mg}^{2+}$ and $\mathrm{K}^{+}$were analyzed to calculate sodium absorption ratios (SAR). However, SAR never surpassed 2.74, a level not critical for plant growth, due to the presence of $\mathrm{Ca}^{2+}$ and $\mathrm{Mg}^{2+}$ ions. On ten plots, $\mathrm{Ca}^{2+}$ concentrations ( 2.5 to $11.7 \mathrm{cmol} \mathrm{kg}^{-1}$ in the topsoil and 2.0 to $14.6 \mathrm{cmol} \mathrm{kg}^{-1}$ in the subsoil) clearly exceeded $\mathrm{Na}^{+}(0.0$ to $5.14 \mathrm{cmol} \mathrm{kg}^{-1}$ in the topsoil and 0.0 to $9.23 \mathrm{cmol} \mathrm{kg}^{-1}$ in the 
Table 1. Characteristics of the novic Arenosol profile in Gunung Kleng.

\begin{tabular}{|c|c|c|c|c|c|c|c|c|c|c|c|c|}
\hline Horizon & $\begin{array}{r}\text { Depth } \\
(\mathrm{cm})\end{array}$ & $\begin{array}{r}\text { Sand } \\
(\%)\end{array}$ & $\begin{array}{r}\mathrm{C} \\
(\%)\end{array}$ & $\begin{array}{r}\mathrm{N} \\
(\%)\end{array}$ & $\begin{array}{r}\text { PBray I } \\
\left(\mathrm{mg} \mathrm{kg}^{-1}\right)\end{array}$ & $\mathrm{pH}$ & $\begin{array}{r}\mathrm{EC} \\
\left(\mu \mathrm{S} \mathrm{cm}^{-1}\right)\end{array}$ & \multicolumn{5}{|c|}{$\left(\right.$ cmolc kg $\left.^{-1}\right)$} \\
\hline Anv1 & $0-5$ & 91 & 0.58 & 0.09 & 1.03 & 5.1 & 61.7 & 4.54 & 0.06 & 0.05 & 1.69 & 1.85 \\
\hline Anv2 & $5-10$ & 79 & 0.35 & 0.05 & 0.90 & 5.2 & 26.1 & 3.04 & 0.02 & 0.02 & 1.29 & 1.69 \\
\hline $\mathrm{AB} 1$ & $10-20$ & 86 & 0.94 & 0.10 & 1.30 & 4.9 & 46.2 & 4.15 & 0.04 & 0.02 & 1.92 & 1.55 \\
\hline $\mathrm{AB} 2$ & $20-28$ & 82 & 0.82 & 0.08 & 1.35 & 4.5 & 19.0 & 4.16 & 0.04 & 0.02 & 0.81 & 1.05 \\
\hline Bw1 & $28-48$ & 83 & 0.23 & 0.01 & 0.68 & 4.5 & 21.6 & 2.16 & 0.09 & 0.03 & 0.60 & 0.45 \\
\hline Bw2 & $>48$ & $\mathrm{Nd}$ & 0.12 & 0.01 & 0.69 & 4.9 & 20.3 & 1.95 & 0.13 & 0.02 & 0.90 & 0.73 \\
\hline
\end{tabular}

$\mathrm{Nd}=$ not determined

Table 2. Characteristics of the arenic Gleysol profile in Gunung Kleng.

\begin{tabular}{lrrrrrrrrrrrr}
\hline Horizon & $\begin{array}{r}\text { Depth } \\
(\mathrm{cm})\end{array}$ & $\begin{array}{r}\text { Sand } \\
(\%)\end{array}$ & $\begin{array}{r}\mathrm{C} \\
(\%)\end{array}$ & $\begin{array}{r}\mathrm{N} \\
(\%)\end{array}$ & $\begin{array}{r}\mathrm{P}_{\text {Bray I }} \\
\left(\mathrm{mg} \mathrm{kg}^{-1}\right)\end{array}$ & $\mathrm{pH}$ & $\begin{array}{r}\mathrm{EC} \\
\left(\mu \mathrm{S} \mathrm{cm}^{-1}\right)\end{array}$ & $\mathrm{CEC}$ & $\mathrm{Na}^{+}$ & $\begin{array}{c}\mathrm{K}^{+} \\
\left(\mathrm{cmolc} \mathrm{kg}^{-1}\right)\end{array}$ & $\begin{array}{c}\mathrm{Ca}^{2+} \\
\mathrm{Mg}^{2+}\end{array}$ \\
\hline Ap1 & $0-10$ & 77 & 3.32 & 0.21 & 0.13 & 5.7 & 142 & 11.79 & 0.16 & 0.02 & 8.08 & 4.51 \\
Ap2 & $10-19$ & 74 & 2.35 & 0.16 & 0.18 & 6.4 & 241 & 7.36 & 0.38 & 0.02 & 6.88 & 3.46 \\
Bw & $19-28$ & 62 & 2.23 & 0.19 & 0.25 & 5.5 & 372 & 4.82 & 0.55 & 0.02 & 3.76 & 2.43 \\
Bg-Bw & $28-45$ & 87 & 0.51 & 0.07 & 1.14 & 5.1 & 399 & 3.65 & 0.50 & 0.05 & 1.30 & 1.03 \\
Bg & $>45$ & Nd & 0.24 & 0.01 & 0.32 & 4.7 & 279 & 2.31 & 0.47 & 0.02 & 0.88 & 1.01 \\
\hline
\end{tabular}

$\mathrm{Nd}=$ not determined

subsoil) and even $\mathrm{Mg}^{2+}$ concentrations $\left(2.5\right.$ to $4.2 \mathrm{cmol} \mathrm{kg}^{-1}$ in the topsoil, and 1.6 to $5.3 \mathrm{cmol} \mathrm{kg}^{-1}$ in the subsoil) were well above $\mathrm{Na}^{+}$concentrations in all but two plots (data not shown).

\subsection{Temporal dynamics of groundwater salinity}

All plots analyzed in the study area could be grouped into four major types of temporal dynamics of groundwater salinity. The first type reflected effects of the tsunami per se; the second and third type were additionally influenced by the flood event in 2007, and the fourth type showed no effect. Figure 4 shows a selection of four transects that include plots representative for each type:

i. Rapid desalinization to stable low values: the tsunamiinduced EC of up to $12 \mathrm{mS} \mathrm{cm}^{-1}$ in 2006 decreased to values below $2 \mathrm{mS} \mathrm{cm}^{-1}$ within one year. This pattern was observed on plots KT 300 to 500 and SS100 (Fig. 4), characterized by free-draining sandy soils, typically situated on beach ridges that were not strongly influenced by changing depth of the groundwater table.

ii. Plots flooded in 2007 (marked with asterisks in Fig. 4) were all close to the seashore (KT150 to 250, ST150 to 700 and SP200 to 350). Salinity levels in 2007 started from a lower level than in 2004 (see Subiksa et al., 2006b), and also returned to pre-flood levels within one season.

iii. Plots indirectly affected by the 2007 flood were found along transect ST up to $1200 \mathrm{~m}$ land inward in the rubber forest on peat soil, and also at SS500, where EC in 2007 quadrupled as compared to 2006 levels, although the plot had not been flooded. These plots showed an increase in salinity beyond seasonal oscillation after May 2007 due to a network of drainage channels extending from the slightly elevated peat domes towards the sea. During and after the flood, flow direction in these channels was reversed and saline water laterally infiltrated into soils. However, rapid restoration to preflood EC levels was observed, as on all plots affected by the 2007 flooding.

iv. Plots showed no direct tsunami or flood impact but seasonal oscillations in EC between drier and wet season 2007, representing the longer-term and large-scale effects of the tsunami event. These were KT400, 700 and 900, SN and, with increasing distance from seawater and elevation, AR150 to 200 and CL (not shown).

\subsection{Interactions between soil and groundwater}

In 2007 depth of the groundwater table differed significantly between seasons (Wilcoxon Signed Ranks test), despite the flood event during the drier season. For the wet season 2007, groundwater depth and EC of soils were significantly negatively correlated $\left(r_{\mathrm{S}}=-0.46^{* *} ; n=46\right)$, meaning that an increase in groundwater table corresponded to increasing salinity in the soil profile. Thus, salinity increased with the higher groundwater table rather than salt concentrations being diluted by rainwater (Fig. 5). 

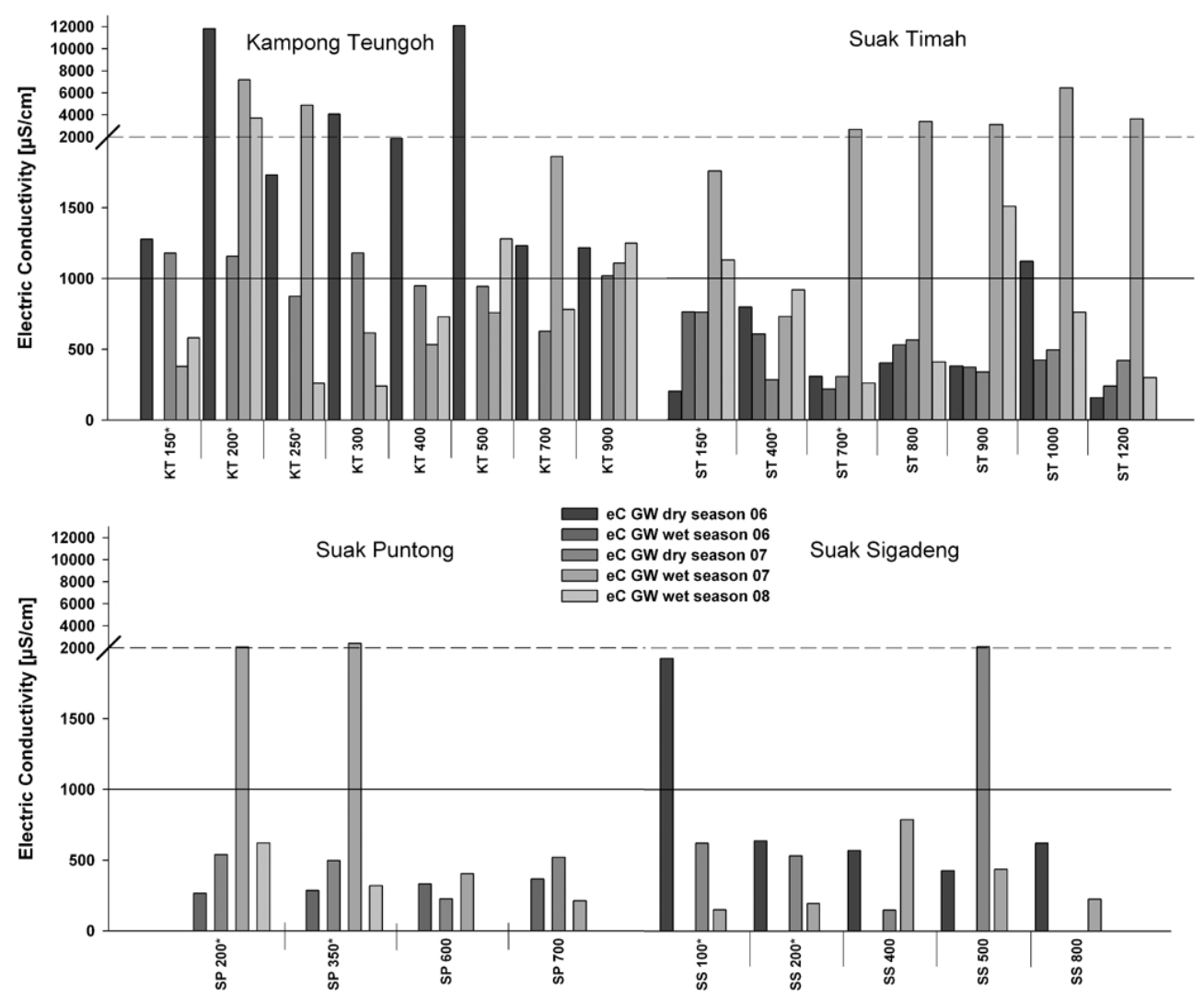

Fig. 4. Temporal dynamics of groundwater salinity from 2006-2008 along four transects in Aceh Barat: (a) Kampong Teungoh; (b) Suak Timah; (c) Suak Puntong; (d) Suak Sigadeng. Numbers after village identifiers indicate distance to the sea in metres. Plots flooded in 2007 are marked with asterisks.

Mud thickness as source of and proxy for salinity showed stronger correlations to groundwater $\mathrm{pH}\left(r_{\mathrm{S}}=0.79^{* *}\right)$ and groundwater $\mathrm{Mg}^{2+}$ concentrations $\left(\mathrm{r}_{\mathrm{S}}=0.77^{* *}\right)$ as compared to soil EC $\left(r_{\mathrm{S}}=0.63 *\right)$, which supposedly reacted more slowly and in a more buffered way to changes. Relative $\mathrm{Na}^{+}$accumulation around $30 \mathrm{~cm}$ profile depth, as in $\mathrm{Bw} 1$ of the novic Arenosol and Bw of the arenic Gleysol (Tables 1 and 2), showed that the leaching front was determined by a dynamic equilibrium of saline groundwater and rainwater infiltration.

\subsection{Tree crop damage and yield depression}

During the tsunami event, flooding with seawater of EC $>40 \mathrm{mS} \mathrm{cm}^{-1}$ lasted for up to five hours and, depending on inundation time, tree crops were severely damaged in large parts of Aceh Barat (Subiksa et al., 2006b). According to farmers (interviewed in 2007), damage symptoms became visible within 6 to 12 months after the flooding. Across all plots, cocoa, rambutan and mango were most severely affected by the tsunami event and its longer-term consequences (Fig. 6). Farmers' assessment of mango damage in 2005 was between 80 and $100 \%$ on all except one plot, and 95 to $100 \%$ for all affected rambutan plots. Coconut, rubber and oil palm

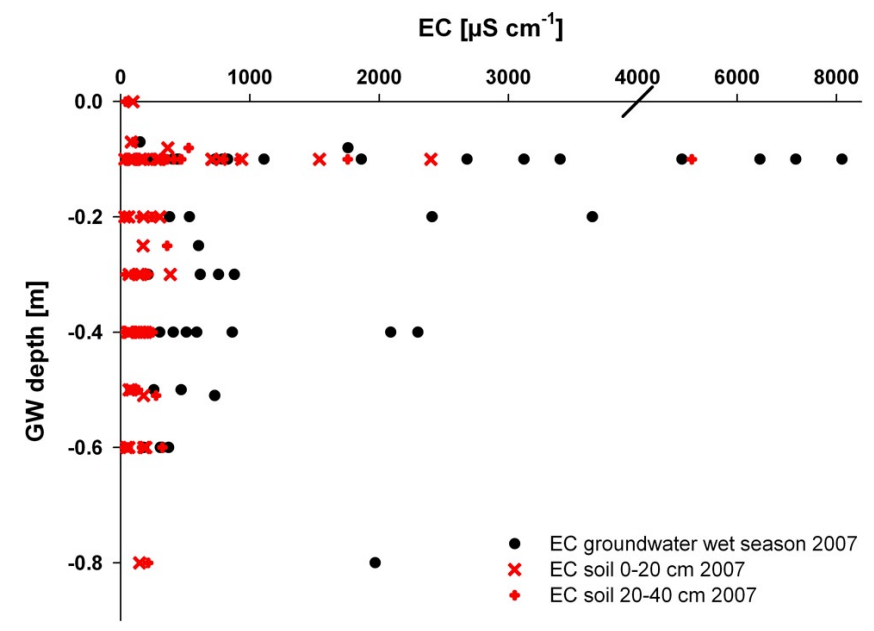

Fig. 5. EC in groundwater (wet season 2007) and two soil layers (May 2007) in relation to groundwater depth.

were less severely affected. Yield depression followed a similar pattern as tree damage.

In addition to farmer interviews, which integrated the period from 2005 to 2007, inventories in 2007 were conducted 


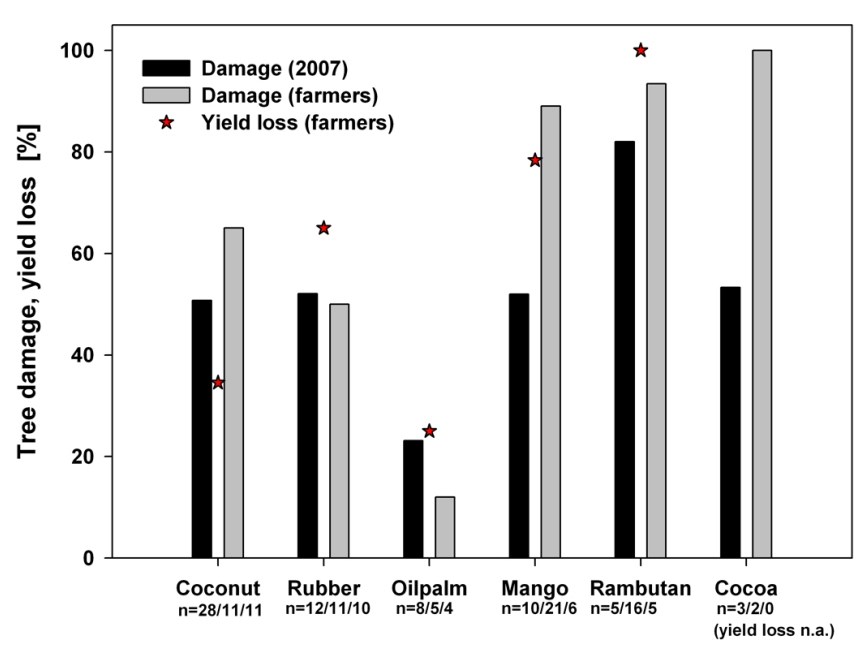

Fig. 6. Tree damage and yield loss in 2005 as reported by farmers and tree damage according to inventories during this study in 2007. Numbers of observations refer to cases of damage as observed in 2007, and damage and yield loss 2005 reported in retrospective by farmers.

as a cross-check. For coconut and rubber, stubs of broken trees were still visible in 2007 and both inventories agreed well. Where entire plots had been cleared or partially replanted, as for cocoa and mango, damage counts diverged between years. Overall, no significant differences between farmers' and damage assessment carried out during this study were found where identical spots were assessed (Wilcoxon signed rank test). Farmers' memory, collective history and caducity of obvious signs appeared not to affect validity of the data.

\subsection{Effects of soil and groundwater parameters on plants}

Despite the rapid decline in salinity after the flooding, groundwater remained saline enough on several transects to dominate soil $\mathrm{Na}^{+}$concentrations and EC once the groundwater table shifted upwards into the rooting space during rainy seasons. Substantial dilution of groundwater by rainwater was not observed. Both long-term soil salinity as well as short-term groundwater oscillations can lead to osmotic stress, $\mathrm{Na}^{+}$toxicity or cation imbalances. Underlying causes could not be differentiated in the field, but statistical relationships between tree damage and soil and groundwater characteristics across all transects allowed to draw some conclusions on potential causes for plant damage and lower yields as reported by farmers.

\subsubsection{Plant damage}

Coconut trees were mostly planted near the coast, and thus tree damage was clearly related to mechanical forces; correlations of damage to run-up height $\left(r_{\mathrm{S}}=0.79 * * ; n=14\right)$ and distance to the sea $\left(r_{\mathrm{S}}=-0.40^{*} ; n=25\right)$ were significant and strong. Significant correlations also existed to soil electric resistivity, the reciprocal of conductivity $\left(r_{\mathrm{S}}=-0.52 * *\right.$; $n=27)$, groundwater $\mathrm{Ca}^{2+}\left(r_{\mathrm{S}}=0.43^{*} ; n=23\right)$ and $\mathrm{pH}$ $\left(r_{\mathrm{S}}=0.46^{*} ; n=23\right)$ in 2007.

Rubber and fruit trees were mostly grown at larger distance (more than 200 to $400 \mathrm{~m}$ ) from the sea, and damage was not correlated to direct physical impact. Damage was strongly correlated to soil electric resistivity, $\left(r_{\mathrm{S}}=-0.72 *\right.$; $n=11)$ and soil $\mathrm{Na}^{+}$concentrations $\left(r_{\mathrm{S}}=0.65^{*} ; n=11\right)$. Correlations to groundwater depth $\left(r_{\mathrm{S}}=-0.69 * ; n=10\right)$ and groundwater EC measured in $2006\left(r_{\mathrm{S}}=0.62, \alpha=\right.$ $0.05 ; n=10$ ) were not expected, because rubber was widely grown on peat domes with insufficient drainage. Damage was thus seen in context with salinity brought by the groundwater, as shown for reversed water flow through drainage channels on transect ST (Fig. 4).

Mango damage was correlated to groundwater EC during the drier season $2007\left(r_{\mathrm{S}}=0.54^{*}, n=15\right)$. For both mango and rubber, farmers reported partial detoxification by leaf shedding. For rambutan damage, a strong statistical relationship was observed against groundwater depth $\left(r_{\mathrm{S}}=0.76^{*}\right)$, implying that the effect could have been caused either directly by groundwater level or by groundwater salinity. Recurring effects of salinity on cocoa could be observed in 2007 on transect GK, where recently planted seedlings showed typical leaf necroses.

\subsubsection{Yield depression}

Yield depression was statistically related to other factors than plant damage. Sufficient numbers of farmer reports for statistical interpretation were obtained only for coconut and rubber. Yield depression in coconut was negatively correlated to groundwater $\mathrm{Mg}^{2+}$ concentration in $2007\left(r_{\mathrm{S}}=\right.$ $-0.77 * * ; n=10)$, and a linear regression with $r^{2}=0.44$ (Fig. 7a) pointed to $\mathrm{Mg}^{2+}$ deficiency. Accordingly, farmers often stated that more nuts with lower individual weight had been harvested in the years following the tsunami. At the same time, yield depression in response to groundwater $\mathrm{Ca}^{2+}$ concentrations and $\mathrm{pH}$ followed a minimum curve with least yield reduction observed on plots around $\mathrm{pH} 5$.

In contrast to coconut, rubber yield depression was generally high, between 40 and $100 \%$ (Fig. 7b). Strong correlations existed to groundwater $\mathrm{Cl}^{-}$in $2006\left(r_{\mathrm{S}}=0.75^{*}\right)$ and soil EC $\left(r_{\mathrm{S}}=0.71^{*}\right)$ as well as to soil $\mathrm{pH}$ at 20 to $40 \mathrm{~cm}$ depth $\left(r_{\mathrm{S}}=-0.73^{*}\right)$, pointing to improved growth conditions on the more alkaline plots. Rubber prefers soil $\mathrm{pH}$ between 5 and 6 and tolerates $\mathrm{pH} 4$ to 8 (Rehm and Espig, 1991), while rubber soils in the area were mostly between 3 and 6.5. Influence of the groundwater was indicated by the fact that rubber yield depression $(n=10)$ was linked to subsoil $\mathrm{Na}^{+}$ $\left(r_{\mathrm{S}}=0.90^{* *}\right)$ more clearly than to topsoil $\mathrm{Na}^{+}\left(r_{\mathrm{S}}=0.80^{*}\right)$. On the other hand, given that rubber is naturally adapted to 
(a)

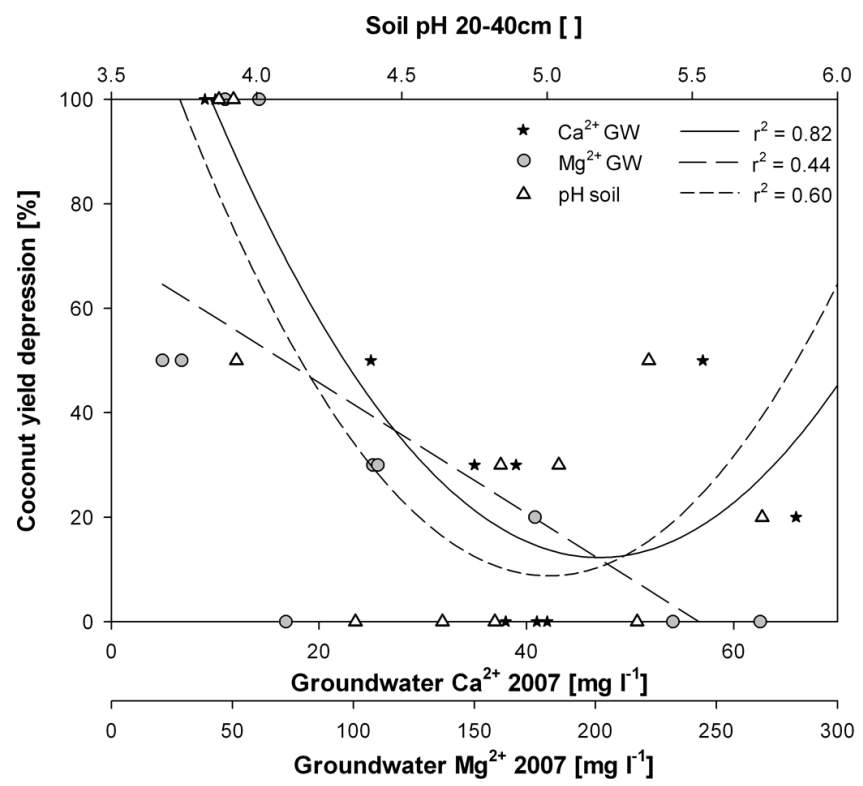

(b)

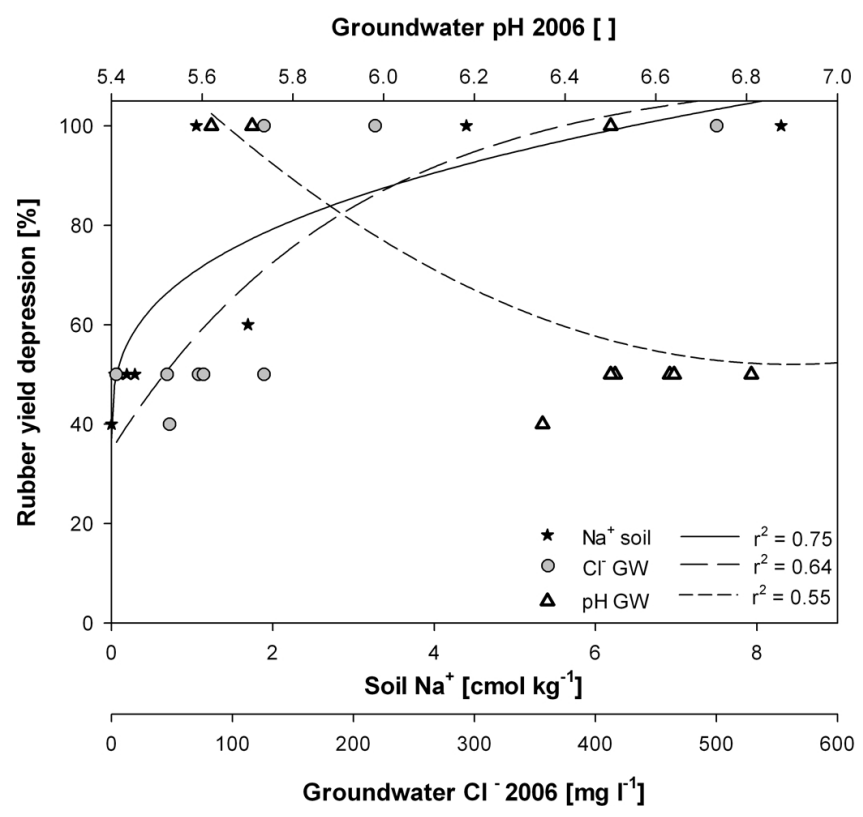

Fig. 7. Response of yield depression in coconut (a) and rubber (b) to soil and groundwater conditions.

periodical water-logging (Kozlowski, 1997), effects of high groundwater per se are unlikely.

The potentially toxic $\mathrm{Na}^{+}$and $\mathrm{Cl}^{-}$ions formed thresholds (around $3 \mathrm{cmol} \mathrm{Na}^{+} \mathrm{kg} \mathrm{soil}^{-1}$ and $100 \mathrm{mg} \mathrm{Cll}^{-1}$ groundwater, resp.), above which yields almost completely failed.

\section{Discussion}

In accordance with previous studies, e.g. Villholth et al. (2005) for Sri Lanka, Rachman (2008) for Aceh, the first main finding of this study was the rapid decline of salinity after the tsunami. Subiksa et al. (2006a) attributed this effect to the sandy texture, low SOM and CEC of the coastal soils in Aceh, which was confirmed on all plots of the present study. The same decline was observed after the post-tsunami flood event in 2007. This event served as a proxy of groundwater dynamics immediately after the tsunami, which had not been part of the field measurements carried out during this study (from 2006 onwards). Second, it was observed that soil salinity-related parameters reflected groundwater dynamics, with a time lag and less extreme maxima. Soil salinization was determined by short-term dynamics due to inundation with sea water and longer-lasting gradual release of salts from tsunami sediments (McLeod et al., 2010). Third, this study showed a periodic increase of groundwater and soil salinity during rainy seasons, a phenomenon that has not received much attention in tsunami research. The fact that groundwater table as well as groundwater and soil salinity increased significantly during the rainy season 2007, despite the flooding in the drier season, suggests that this increase occurs to the same or higher extent in other years, too. Likewise, Rachman (2008) found drastically elevated soil salinity during seasons of high groundwater table in Aceh Pidie and Aceh Besar, $250 \mathrm{~km}$ from the area in this study. This implies that the diluting effect of rainfall was overruled by ion release from tsunami mud and uplift of saline groundwater. It can be assumed that upward movement of saltwater in the soil (leading to higher EC at higher groundwater levels) may have been caused by groundwater recharge in the more elevated hinterland and peat areas during the wet season, exerting upward pressure on the saline groundwater bodies closer to the coast. The deeper parts of these groundwater aquifers, originating in the hills, were tapped for new wells installed after the tsunami. Alternatively, a model developed by Illangasekare et al. (2006) for Sri Lanka, assumes that tsunami seawater infiltrated a freshwater lens situated above a seawater wedge. The mixed water body would then be subject to seasonal oscillations of the groundwater table. Given the high annual precipitation in Aceh Barat, it can be assumed that groundwater and seawater bodies are still connected in places where geomorphology has been altered by the tsunami. Fourth, the observed effects of soil salinization extended outside the flooded areas, presumably driven by lateral infiltration of groundwater. In the soil profiles analyzed for this study, leaps of single cation concentrations were found. In contrast to a typical leaching front, this boundary is assumedly shifted upwards during rainy seasons.

As these effects prevail in groundwater-influenced soil horizons, available rooting space above groundwater level played a decisive role for salinity effects on plants. In this context, the influence of small-scale topography - ridges and 
swales oriented in parallel direction to the coastline - was decisive for mud deposition, groundwater table and plant growth. Umitsu et al. (2007) found that route and intensity of the tsunami backwash were mainly determined by microrelief on the beaches; during the sedimentation process, depressions were filled up with mud first (Rachman, 2008; Paris et al., 2007), as reflected in our study by alternating points of high and low salinity in the monitored transects (e.g. KT, SS). Thus, groundwater level is seen as a function of micro-relief, influential for plant growth in the mid to long run. Effects of scale became obvious when relief-related parameters measured at different spatial resolution were correlated: Mud thickness, groundwater $\mathrm{pH}$ and $\mathrm{Mg}^{2+}$ measured at the 48 transect points were well-correlated among each other, and so were mud thickness and resistivity at $5 \mathrm{~m}$ depth extracted for the same points from interpolated large-scale maps from the ReGrIn project and Siemon et al. (2007), respectively. Between point data and interpolated data, however, no significant correlation was found.

While most tsunami research after 2004 concentrated on damage to humans and property, our study links groundwater and soil salinity-related parameters and their effects on agriculture, in particular tree crops, which are deep rooting and thus sensitive in areas of shallow groundwater table. Apart from initial salinization and water-logging of tsunami-affected soils, recurring salinity and cation imbalances during periods of high groundwater levels or lateral flow were the most relevant impact factors constraining tree crop growth in post-tsunami Aceh Barat. Given more than $3600 \mathrm{~mm}$ average rainfall per year, leaching of salts out of the soil was not limited by source, but by sink, i.e. groundwater-influenced soil horizons. Recommendations targeting shallow-rooting annual crops, such as increasing soil organic matter contents or facilitating flushing and leaching (Slavich et al., 2008), will be largely ineffective for tree crops, once rooting systems extend into saline soil horizons. Although tree crops may dispose of detoxification by mechanisms like leaf shedding, damage caused by salinity and associated yield depression may last longer than for annuals.

Mechanical damage to tree crops could clearly be related to distance from the sea shore, in accordance with findings on human mortality and damage to buildings in the same area (Laso Bayas et al., 2011). Consequently, mostly coconut was affected by breakage, while other tree crops suffered from salinity-related impact. This is in line with agronomic data about salt sensitivity of rambutan (FAO and MOAC, 2005) and mango and notorious salt tolerance of coconut (FAO, 2005).

Yield depression was often indirectly related to microrelief effects, e.g. in the case of rubber and mango. Here, depth of the - saline - groundwater table affected soil and groundwater $\mathrm{pH}$ and single ion concentrations, which changed markedly after the tsunami. Rubber yield depression was correlated stronger to $\mathrm{Na}^{+}$in the subsoil than in the topsoil, pointing to advanced leaching of seawater and recurring effects of groundwater. Effects of groundwater $\mathrm{pH}$ on plants appeared less influential than those of salinity. Although literature on salinity or seawater effects on rubber is scarce, the role of $\mathrm{K}^{+}$for latex flow rates is well-known (Pushparajah and Guha, 1969) and $\mathrm{KCl}$ fertilization of rubber is reported for saline soils in Eastern Thailand (Mak et al., 2008), so that competitive effects between $\mathrm{Na}^{+}$and $\mathrm{K}^{+}$(in the soil or plant) may explain reduction in latex yield. The fact that a wide range of $\mathrm{pH}$ values was found across the rubber plots points to $\mathrm{Na}^{+}$as most influential factor for yield depression.

Despite their position further land inward, none of the surveyed rubber plots had less than $40 \%$ yield depression, similar to the high damage levels in rambutan, cocoa and partly mango. Coconut trees were less affected by physiological constraints despite being exposed to higher salinity and alkalinity. Where $\mathrm{Mg}^{2+}$ was deficient despite its high concentrations in tsunami mud, it may have been displaced by comparably higher concentrations of $\mathrm{Ca}^{2+}$ ions from exchange sites or competed for uptake into plants. This is in line with reports and analyses of coconut leaves exhibiting chlorosis as a symptom of $\mathrm{Mg}^{2+}$ deficiency (Subiksa et al., 2006b). A comparative advantage of coconut over other trees may have been their superficial rooting system. Deep rooting trees were better anchored in the soil and thus more resistant to the physical impact of the tsunami. On the other hand, they were more exposed to the longer-lasting effects of saline groundwater during rainy seasons.

As modifications to the landscape relief, hydrology and ecology are currently effectuated at larger scale (introduction of new industrial crops like oil palm in large estates replacing jungle rubber) and negative effects become visible (peat drainage followed by slash and burn, soil compaction, among others), the importance of crop-site matching cannot be overemphasized, to which tsunami reconstruction efforts did not always adhere (Laso Bayas et al., 2011). In summary, tree crops most affected by flooding were those planted outside their natural habitat. Replanting of tree crops should consider adapted species such as Nypa fruticans and other tree crops that are resistant to seawater and at the same time consider initial investments and profitability (Mattsson et al., 2009).

Imposed by the circumstances during the tsunami aftermath, this study is based on a limited number of repeated observations on a coastal strip of about $40 \mathrm{~km}$ and does not represent a spatially exhaustive dataset. Still, general trends of groundwater and soil salinity distribution and temporal dynamics could be identified, which add new aspects to existing research.

\section{Conclusions}

Spatially, salinization patterns were determined by distance to salt water bodies, unless overruled by the influence of groundwater level, e.g. in places of lower elevation near 
ditches or swales. Temporally, flood- and mud-borne salinity of soils decreased quickly after a flooding event, but recurring elevated salinity was observed during seasons of high groundwater levels. Groundwater salinity reacted more quickly and more strongly to flood events, while the soil buffered salinity over longer periods. Fruit trees - mango, rambutan, cocoa - were generally sensitive to the tsunami effects, and mortality was high. Disentangling effects of high groundwater level and salinity on fruit tree mortality were not possible, while the most influential damaging factors for coconut were mechanical forces and for rubber salinity-related soil and groundwater parameters. Yield depression of coconut appeared to be related mainly to cation imbalances in the groundwater, while rubber yields were affected by soil sodium contents (possibly interfering with $\mathrm{K}$ uptake) and groundwater $\mathrm{pH}$. Given the large areas affected and the recurring and thus long-lasting effects particularly trees are exposed to under these conditions, modification of the soil and landscape appears to be of limited efficacy to improve growing conditions. Selection of shallow rooting or salt-resistant crops for agriculture appears to be a more promising strategy. Apart from profitability of these plants, protective effects in case of expected future tsunamis should be considered.

Acknowledgements. Bundesanstalt für Geowissenschaften und Rohstoffe, Hannover, Germany, provided resistivity maps of the study region. Aulia Firdaus was essential for reliable and thorough sampling and logistic support on site. Yohannes Zergaw Ayanu and Thi Thanh Nguyen elaborated the maps. This study was carried out within the ReGrIn project, Rebuilding Green Infrastructure with Trees People Want, funded by the European Commission through the ECO ASIA IIb programme (ASIE 2005/111/657). We are grateful to Peter Slavich and an anonymous reviewer for their comments on an earlier version of this paper.

Edited by: S. Tinti

Reviewed by: P. Slavich and one anonymous referee

\section{References}

Agus, F., Subagjo, H., Rachman, A., and Subiksa, I. G. M.: Properties of Tsunami Affected Soils and the Management Implication, 2nd Int Salinity Forum, Adelaide, Australia 31 March-3 April 2008, available at: www.internationalsalinityforum.org (last access: 16 March 2010), 2008.

Badan Meteorologi dan Geofisika, Stasiun Meteorologi Meulaboh: Data Curah Hujan Tahun 2004-2007. Badan Meteorologi dan Geofisika, Meulaboh, Indonesia, 2008.

Bray, R. H. and Kurtz, L. T.: Determination of total organic and available forms of phosphorus in soils, Soil Sci., 59, 39-45, 1945.

Chaerun, S. K., Wirth, S., Ulrich, A., Ellerbrock, R. H., and Maassen, S.: Impact of seawater flooding caused by the 26 December 2004 tsunami disaster on physico-chemical and microbial properties of arable soils in Banda Aceh, Indonesia, in: Book of Abstracts Eurosoil, 25-29 August 2008, Vienna, Austria, p. 36, 2008.
Chaudary, D. R., Ghosh, A., and Patolia, J. S.: Characterization of soils in the tsunami-affected coastal areas of Tamil Nadu for agronomic rehabilitation, Curr. Science, 91, 99-104, 2006.

FAO: Field Guide -20 things to know about the impact of salt water on agricultural land in Aceh province, FAO, Rome, 2005.

FAO and MOAC: Report of Joint FAO/MOAC Detailed Technical Damages and Needs Assessment Mission in Fisheries and Agriculture Sectors in Tsunami Affected Six Provinces in Thailand, 11-24 January 2005, FAO, Rome, 2005.

FAO, ISRIC and ISSS: World Reference Base for Soil Resources, FAO, Rome, 2006.

Illangasekare, T., Tyler, S. W., Clement, T. P., Villholth, K. G., Perera, A., Obeysekera, J., Gunatilaka, A., Panabokke, C. R., Hyndman, D. W., Cunningham, K. J., Kaluarachchi, J. J., Yeh, W. W., van Genuchten, M. T., and Jensen, K.: Impacts of the 2004 tsunami on groundwater resources in Sri Lanka, Water Resour. Res., 42, 1-9, 2006.

Joshi, L. and Nugraha, E.: Livelihood and environment in Aceh and Nias: The role of tree crops in post-tsunami development, in: Proc Int Symp Land Use after the Tsunami: Supporting Education, Research and Development in the Aceh Region, Banda Aceh, 4-6 November 2008, 2008.

Kozlowski, T. T.: Responses of woody plants to flooding and salinity, Tree Physiol. Monogr., Heron Publishing, Victoria, Canada, 1997.

Laso Bayas, J. C., Marohn, C., Dercon, G., Dewi, S., Piepho, H. P., Joshi, L., van Noordwijk, M., and Cadisch, G.: Influence of coastal vegetation on the 2004 tsunami wave impact in west Aceh, Proc. Natl. Aca. Sci., 108, 18612-18617, 2011.

Mak, S., Chinsathit, S., Pookpakdi, A., and Kasemsap, P.: The effect of fertilizer and irrigation on yield and quality of rubber (Hevea brasiliensis) grown in Chanthaburi Province of Thailand, Kasetsart, J. Nat. Sci., 42, 226-237, 2008.

Mattsson, E., Ostwald, M., Nissanka, S. P., Holmer, B., and Palm, M.: Recovery and protection of coastal ecosystems after tsunami event and potential for participatory forestry CDM - Examples from Sri Lanka, Ocean Coast. Manag., 52, 1-9, 2009.

McLeod, M. K., Slavich, P. G., Irhas, Y., Moore, N., Rachman, A., Ali, N., Iskandar, T., Hunt, C., and Caniago, C.: Soil salinity in Aceh after the December 2004 Indian Ocean tsunami, Agr. Water Manage., 97, 605-613, 2010.

Munshower, F. F.: Practical Handbook of Disturbed Land Revegetation, Lewis, Boca Raton, Florida, 1994.

Pagel, H., Enzmann, J., and Mutscher, H.: Pflanzennährstoffe in tropischen Böden - ihre Bestimmung und Bewertung, Deutscher Landwirtschaftsverlag, Berlin, 1982.

Paris, R., Lavigne, F., Wassmer, P., and Sartohadi, J.: Coastal sedimentation associated with the December 26, 2004 tsunami in Lok Nga, West Banda Aceh (Sumatra, Indonesia), Mar. Geol., 238, 93-106, 2007.

Pushparajah, E. and Guha, M. M.: Fertilizer response in Hevea brasiliensis in relation to soil type and leaf nutrition studies, Transactions of the Ninth International Congress on Soil Science Adelaide, 1969.

Rachman, A.: Rehabilitation of tsunami-affected soil in NAD, in: Proc Int Symp Land Use after the Tsunami: Supporting Education, Research and Development in the Aceh Region, Banda Aceh, 4-6 November 2008, 2008. 
Rehm, S. and Espig, G.: The cultivated plants of the Tropics and Subtropics, Margraf Verlag, Weikersheim, 1991.

Schlichting, E., Blume, H. P., and Stahr, K.: Bodenkundliches Praktikum. Blackwell, Berlin, 1995.

Schollenberger, C. J. and Simon, R. H.: Determination of exchange capacity and exchangeable bases in soils - ammonium acetate method, Soil Sci., 59, 13-24, 1945.

Shofiyati, R., Dimyati, R. D., Kristijono, A., and Wahyunto: Tsunami effect in Nanggroe Aceh Darussalam and North Sumatra Provinces, Indonesia, Asian J. Geoinform., 5, 100-111, 2005.

Siemon, B., Steuer, A., Meyer, U., and Rehli, H.-J.: HELP ACEH A post-tsunami helicopter-borne groundwater project along the coasts of Aceh, northern Sumatra, Near Surf. Geophys., 5, 231240, 2007.

Slavich, P., McLeod, M., Moore, N., Tinning, G., Lines-Kelly, R., Iskandar, T., Rachman, A., Agus, F., and Yufdy, P.: Tsunami impacts on farming in Aceh and Nias, Indonesia,. 2nd Int Salinity Forum, Adelaide, Australia 31 March-3 April 2008, available at: www.internationalsalinityforum.org (last access: 16 March 2010), 2008.

Subiksa, I. G. M. and Agus, F.: Salinity dynamics of tsunami affected soils in the coastal area of West Aceh, in: Proc Int Symp Land Use after the Tsunami: Supporting Education, Research and Development in the Aceh Region, Banda Aceh, 4-6 November 2008, 255-258, 2008.

Subiksa, I. G. M., Agus, F., and Erfandi, D.: The salt leached out and the soil fertility changes after tsunami, ICRAF Research Bulletin November 2006, ICRAF South East Asia, Bogor, 2006a.

Subiksa, I. G. M., Agus, F., and Erfandi, D.: Soil monitoring and tree crops adaptability after tsunami in West Aceh district, Report, Indonesian Soil Research Institute, Bogor, Indonesia, $2006 b$.
Szczuciński, W., Chaimanee, N., Niedzielski, P., Rachlewicz, G., Saisuttichai, D., Tepsuwan, T., Lorenc, S., and Siepak, J.: Environmental and Geological Impacts of the 26 December 2004 Tsunami in Coastal Zone of Thailand - Overview of Short and Long-Term Effects, Pol. J. Environ. Stud., 15, 793-810, 2006.

The Consultative Group of Indonesia (CGI): Indonesia: Preliminary damage and loss assessment. The December 26, 2004 Natural Disaster, Report, BAPPENAS, Jakarta, available at: www.unep.org/tsunami/reports/damage_assessment.pdf (last access: 16 March 2012), 2005.

Umitsu, M., Tanavud, C., and Patanakanog, B.: Effects of landforms on tsunami flow in the plains of Banda Aceh, Indonesia, and Nam Khem, Thailand, Mar. Geol., 242, 141-153, 2007.

Verrelst, J. and Schaepman, M. E.: Damage assessment of a coastal plain based on satellite imagery, in: Your environment is our concern: A catalogue of worldwide environmental research, Alterra and the Environmental Sciences Department of Wageningen University, Netherlands, 78-81, 2007.

Villholth, K. G., Amerasinghe, P. H., Jeyakumar, P., Panabokke, C. R., Woolley, O., Weerasinghe, M. D., Amalraj, N., Prathepaan, S., Bürgi, N., Lionelrathne, D. M., Indrajith, N. G., and Pathirana, S. R.: Tsunami Impacts on Shallow Groundwater and Associated Water Supply on the East Coast of Sri Lanka, IWMI, Colombo, Sri Lanka, 2005.

Wahyunto, Ritung, S., Wahdini, W., and Agus, F.: Alternative Tree Crops for Reconstruction of the Green Infrastructure PostTsunami in the Coastal Areas of Aceh Barat District, Indonesian J. Agr. Sci., 10, 1-11, 2009. 